\title{
Efektivitas Ekstrak Bunga Rosella (Hibiscus Sabdariffa L.) Sistemik Terhadap Penyembuhan Ulser Pada Tikus Wistar (Rattus Norvegicus)
}

\author{
(Effectiveness of Systemic Rosella (Hibiscus Sabdariffa L.) Extract Against Ulcer Healing in Wistar Rats \\ (Rattus Norvegicus)
}

\author{
Nindita Cahya Mumpuni' ${ }^{1}$, lin Eliana Triwahyuni², Pujiana Endah Lestari \\ 1 Fakultas Kedokteran Gigi Universitas Jember \\ 2 Bagian Penyakit Mulut Fakultas Kedokteran Gigi Universitas Jember \\ 3 Bagian Mikrobiologi Fakultas Kedokteran Gigi Universitas Jember
}

\begin{abstract}
Abstrak
Ulser merupakan lesi terbuka pada mukosa rongga mulut yang umumnya dipicu oleh berbagai penyebab antara lain trauma, hormonal, agen infeksi, defisiensi nutrisi, serta berbagai kelainan sistemik lainnya. Pengobatan dibutuhkan untuk mencegah terjadinya infeksi sekunder, mengurangi inflamasi, mengurangi rasa nyeri dan mempercepat penyembuhan lesi. Rosella berkhasiat meningkatkan daya tahan tubuh, antiinflamasi, antibakteri dan bersifat antioksidan. Kemampuan tersebut diperoleh dari kandungan kimia berupa flavonoid, tanin, fenol, antosianin dan saponin. Tujuan penelitian adalah untuk mengetahui efek pemberian ekstrak rosella secara sistemik terhadap waktu penyembuhan dan diameter ulser serta mengetahui dosis ekstrak rosella yang efektif terhadap penyembuhan ulser pada tikus wistar. 20 ekor tikus dibuat ulser pada bukal kiri dengan memanaskan amalgam stopper diatas api Bunsen selama 30 detik dan disentuhkan selama satu detik kemudian ditunggu 48jam. Semua kelompok disondenase dengan kelompok Vitamin $C(K+)$, kelompok tanpa perlakuan (K-) dan kelompok perlakuan yang terdiri dari kelompok dosis $0,17 \mathrm{mg} / \mathrm{gBB}(\mathrm{P} 1), 0,33 \mathrm{mg} / \mathrm{gBB}(\mathrm{P} 2)$, dan $0,66 \mathrm{mg} / \mathrm{gBB}(\mathrm{P} 3)$. Pemberian perlakuan dilakukan dua kali sehari dan pengukuran diameter ulser dengan meletakkan plastic filling instrument sepanjang ulser kemudian ditandai dan diukur dengan sliding caliper dilakukan setiap hari hingga ulser sembuh. Waktu penyembuhan dan penurunan diameter ulser lebih cepat pada kelompok perlakuan daripada kelompok kontrol. Penyembuhan ulser paling cepat pada ekstrak rosella dosis $0,17 \mathrm{mg} / \mathrm{gBB}$. Kesimpulannya ekstrak rosella dengan dosis $0,17 \mathrm{mg} / \mathrm{gBB}$ memberikan pengaruh paling efektif terhadap penyembuhan ulser.
\end{abstract}

Kata Kunci: ulser, ekstrak rosella, waktu penyembuhan diameter ulser

Abstract

Ulcer is an open lesion in the oral mucosa which is generally triggered by various causes including trauma, hormonal, infectious agents, nutritional deficiencies, and various other systemic abnormalities. Treatment is needed to prevent secondary infections, reduce inflammation, reduce pain and speed healing. Rosella efficacious to increase endurance, anti-inflammatory, antibacterial and antioxidant. This ability is obtained from flavonoids, tannins, phenols, anthocyanins and saponins. The purpose was to determine the effect of systemic rosella extract on healing time and ulcer diameter and to determine the effective dose of rosella extract on ulcer healing in wistar rats. 20 rats were ulcered on the left buccal by heating the amalgam stopper over the Bunsen fire for 30 seconds and touching for one second then waiting for 48 hours. All groups were condensed with the Vitamin $C$ group $(K+)$, the untreated group (K-) and the treatment group which consisted of $0.17 \mathrm{mg} / \mathrm{gBB}(\mathrm{Pl}), 0.33 \mathrm{mg} / \mathrm{gBB}(\mathrm{P} 2)$, and $0.66 \mathrm{mg} / \mathrm{gBB}(\mathrm{P} 3)$. The treatment is done twice a day and the measurement of diameter by placing a plastic filling instrument along the ulcer is then marked and measured with a digital calipers carried out every day until the ulcer heals. Healing time and decrease in ulcer diameter were faster in the treatment group than in the control group. Fastest ulcer healing in roselle extract dose 0.17 $\mathrm{mg} / \mathrm{gBB}$. The conclusion described Roselle extract with a dose of $0.17 \mathrm{mg} / \mathrm{gBB}$ gives the most effective effect on ulcer healing.

Keywords: ulcer, rosella extract, healing time of ulcer diameter

Korespondensi (Correspondence) : Nindita Cahya Mumpuni. Fakultas Kedokteran Gigi, Universitas Jember. Alamat: Jalan Kalimantan No.37, Kampus Tegal Boto, Jember, Jawa Timur 08121. Email: nindhitamumpuni10@gmail.com

Ulser merupakan lesi terbuka pada mukosa rongga mulut yang menyebabkan sebagian struktur epitel hilang hingga melebihi membran basalis.' Ulser umumnya dipicu oleh berbagai penyebab antara lain trauma mekanik, trauma kimia, agen infeksi, gangguan sistem imun, defisiensi nutrisi, serta berbagai kelainan sistemik lainnya. ${ }^{2}$ Recurrent Apthous Stomatitis (RAS) dan traumatik ulser merupakan lesi ulserasi yang sering dijumpai pada rongga mulut. Prevalensi traumatik ulser pada mukosa rongga mulut cukup tinggi yaitu sekitar $83,6 \%$.

Traumatik ulser adalah suatu lesi pada rongga mulut yang terjadi karena tergigit, terkena sikat gigi, makanan yang kasar dan tajam, luka bakar akibat makanan dan minuman yang terlalu panas, dan terbentur benda tajam lainnya. ${ }^{3}$

Adanya epitel yang terbuka dapat menyebabkan terjadinya infeksi sekunder, dimana lesi tersebut berpotensi menjadi port de entry mikroorganisme. Pengobatan dibutuhkan untuk mencegah terjadinya infeksi sekunder, mengurangi inflamasi, mengurangi rasa nyeri dan mempercepat penyembuhan lesi. ${ }^{4}$

Rosella (Hibiscus sabdariffa L.) secara empiris berkhasiat sebagai antiseptik, diuretik, meningkatkan daya tahan tubuh, antiinflamasi, antibakteri dan bersifat antioksidan. ${ }^{5}$ Rosella memiliki komponen 
fitokimia potensial meliputi fenol, alkaloid, tannin, flavonoid, saponin, asam organik, antosianin, dan polisakarida. ${ }^{6}$ Penelitian tentang efektivitas antiinflamasi ekstrak rosella terhadap tikus wistar yang diinduksi caragenan melaporkan dosis yang memiliki efek paling baik sebagai antiinflamasi adalah dosis 326.16 $\mathrm{mg} / \mathrm{KgBB}$ dengan menghambat pembentukan radang $74.524 \%$ yang setara dengan obat pembanding tablet natrium diklofenak $(4,5 \mathrm{mg} / \mathrm{KgBB}){ }^{7}$ Penelitian lain menyebutkan ekstrak rosella dengan dosis 410 $\mathrm{mg} / 200 \mathrm{gBB}$ untuk pengujian di tikus putih jantan galur Wistar memiliki aktivitas antiinflamasi dengan persentase penghambatan radang sebesar $31,93 \% .8$ Penelitian in vivo pemberian sistemik ekstrak etanolik rosella dapat menghambat ekspresi COX-2 dan menurunkan jumlah neutrofil fase inflamasi sehingga mempercepat proses penyembuhan luka. ${ }^{9}$ Penelitian secara in vitro untuk mengkaji potensi antioksidan dan daya hambat terhadap enzim siklooksigenase bunga rosella menunjukkan bahwa kandungan ekstrak bunga rosela mampu menghambat enzim siklooksigenase sehingga menghambat sistesis leukotriene \& prostaglandin yang merupakan mediator inflamasi. 10

Penelitian sebelumnya mengenai perbandingan perawatan secara sistemik dan topikal pada Recurrent Aphthous Stomatitis (RAS) dimana perawatan secara sistemik lebih efektif karena dapat meredakan rasa sakit dan menyembuhkan ulser mayor lebih cepat."1 Sudah ada beberapa penelitian obat ulser dalam sediaan topikal berupa krim ataupun gel. Namun pemberian perawatan topikal dalam bentuk krim akan sulit melekat lama di mukosa rongga mulut karena sifatnya yang mudah larut dalam saliva. ${ }^{12}$ Berdasarkan kandungan kimia yang terdapat dalam ekstrak rosella dan beberapa penelitian tersebut, perlu diteliti dosis efektif pemberian ekstrak rosella secara sistemik terhadap penyembuhan ulser yang diuji pada model traumatik ulser pada tikus putih wistar yang dilukai.

\section{METODE PENELITIAN}

Jenis penelitian ini adalah penelitian eksperimen laboratories dengan rancangan penelitian the post test only control group design. Penelitian ini dilaksanakan di Laboratorium Biomedik Fakultas Kedokteran Gigi Universitas Jember yang sebelumnya dilakukan pengurusan ethical clearance di Komisi Etik Penelitian Kesehatan Fakultas Kedokteran Gigi Universitas Jember dan identifikasi tanaman Rosella (Hibiscus sabdariffa L.) di Fakultas Matematika dan IImu Pengetahuan Alam. Sampel yang digunakan adalah 20 ekor tikus yang dibuat ulser pada bukal kiri dengan memanaskan amalgam stopper diatas api Bunsen selama 30 detik dan disentuhkan selama 1 detik kemudian ditunggu 48 jam. Semua kelompok disondenase dengan kelompok Vitamin $C(\mathrm{~K}+)$, kelompok tanpa perlakuan (hanya diberi aquades) (K-) dan kelompok perlakuan yang terdiri dari kelompok dosis $0,17 \mathrm{mg} / \mathrm{gBB}$ (P1), 0,33 mg/gBB (P2), dan $0,66 \mathrm{mg} / \mathrm{gBB}$ (P3). Pemberian perlakuan dilakukan dua kali sehari dan pengukuran diameter ulser dengan meletakkan plastic filling instrument sepanjang ulser kemudian ditandai dan diukur dengan jangka sorong digital dilakukan setiap hari hingga ulser sembuh. Setelah itu waktu penyembuhan dan diameter ulser dihitung dan dianalisis.

\section{HASIL}

Berdasarkan penelitian yang telah dilakukan, rata-rata diameter ulser pada masing-masing kelompok, yaitu kelompok kontrol positif, kelompok kontrol negatif dan kepompok perlakuan ekstrak rosella dengan dosis $0.17 \mathrm{mg} / \mathrm{gBB}, 0.33 \mathrm{mg} / \mathrm{gBB}$ dan 0.66 $\mathrm{mg} / \mathrm{gBB}$ perharinya ditampilkan pada Gambar 1. Dari grafik rata-rata diameter ulser tersebut menunjukkan adanya penurunan ukuran diameter lesi setiap harinya pada semua kelompok. Grafik tersebut juga menunjukkan bahwa terdapat perbedaan waktu penyembuhan pada setiap kelompok, kelompok perlakuan dengan pemberian ekstrak rosella dosis $0,17 \mathrm{mg} / \mathrm{gBB}$ (P1) mengalami penyembuhan paling cepat yaitu 7 hari, sedangkan pada kelompok kontrol negatif mengalami penyembuhan paling akhir yaitu selama 11 hari.

Data yang diperoleh kemudian diuji normalitasnya dengan uji Shapiro-Wilk didapatkan hasil analisis waktu sembuh menunjukkan data tidak berdistribusi normal dengan nilai signifikan $(p)<0.05$ dan varian data homogen dengan nilai signifikansi (p) $>0.05$ yaitu 0.332 sehingga diasumsikan tidak memenuhi uji normalitas. Data dilanjutkan dengan uji non parametrik Kruskal Wallis dan Mann-Whitney dan terdapat perbedaan yang bermakna antara $\mathrm{K}(-)$ dengan semua kelompok, antara $K(+)$ dengan $P(1)$ dan $P(2)$, serta antara $P(1)$ dengan $P(3)$. Sedangkan untuk diameter ulser uji beda menggunakan One Way Anova untuk data yang berdistribusi normal dan homogen, uji Kruskall Wallis untuk data yang tidak berdistribusi normal dan homogen.

Hasil uji One Way Anova terdapat perbedaan yang signifikan antar kelompok pada semua hari, kecuali hari kedua dan dilanjutkan uji LSD. Hasil uji Kruskall Wallis terdapat perbedaan yang signifikan antar kelompok pada semua hari, kecuali hari pertama dan dilanjutkan uji Mann-Whitney. Selanjutnya dilakukan uji efektivitas untuk mengetahui nilai efektivitas pada kelompok perlakuan $\mathrm{P}(1), P(2)$ dan $\mathrm{P}(3)$. Hasil perhitungan kelompok perlakuan yang memiliki efektivitas paling baik dalam menyembuhkan ulser adalah ekstra rosella dosis $0,17 \mathrm{mg} / \mathrm{gBB}$. 
Tabel 1. Rata-rata diameter ulser

\begin{tabular}{|c|c|c|c|c|c|c|c|c|c|c|c|}
\hline \multirow{2}{*}{ Kelompok } & \multicolumn{11}{|c|}{ Observasi hari ke- } \\
\hline & 1 & 2 & 3 & 4 & 5 & 6 & 7 & 8 & 9 & 10 & 11 \\
\hline $\mathrm{K}(-)$ & 2.32 & 2.27 & 2.23 & 2.17 & 1.94 & 1.74 & 1.31 & 0.85 & 0.5 & 0.13 & 0 \\
\hline$K(+)$ & 2.21 & 2.14 & 1.83 & 1.48 & 1.20 & 0.89 & 0.59 & 0.27 & 0.06 & 0 & 0 \\
\hline $0,17 \mathrm{mg} / \mathrm{gBB}$ & 2.26 & 2.14 & 1.58 & 1.13 & 0.68 & 0.21 & 0 & 0 & 0 & 0 & 0 \\
\hline $0,33 \mathrm{mg} / \mathrm{gBB}$ & 2.24 & 2.17 & 1.69 & 1.30 & 0.89 & 0.44 & 0.20 & 0 & 0 & 0 & 0 \\
\hline $0,66 \mathrm{mg} / \mathrm{gBB}$ & 2.28 & 2.22 & 1.96 & 1.69 & 1.31 & 0.96 & 0.49 & 0.11 & 0 & 0 & 0 \\
\hline
\end{tabular}

\section{PEMBAHASAN}

Hasil penelitian menunjukkan hari sembuh secara berurutan ( $\mathrm{Pl}$ ) pada hari ke-7, (P2) pada hari ke-8, (P3) pada hari ke-9, (K+) pada hari ke 10 dan K(-) pada hari ke 11 . Adanya perbedaan waktu penyembuhan antara kelompok kontrol negatif dan kelompok perlakuan disebabkan karena adanya kandungan bioaktif dalam ekstrak rosella meliputi fenol, alkaloid, tannin, flavonoid, saponin, asam organik, antosianin, dan polisakarida. ${ }^{7}$

Peningkatan hari sembuh pada (P2) dan (P3) dimungkinkan karena kandungan bioaktif ekstrak rosella sudah terlalu tinggi atau melibihi yang dibutuhkan tubuh, sehingga fungsi antosianin dan flavonoid dalam ekstrak rosella sudah tidak optimal. Pemberian ekstrak rosella dosis tinggi kurang efektif sebagai antiinflamasi dikarenakan kadar flavonoid sebagai antiinflamasi mengalami penurunan aktivitas pada konsentrasi ekstrak yang tinggi. Selain itu, penambahan kandungan antosianin sebagai antioksidan yang berlebihan akan memerusak jaringan7. Penurunan efek ekstrak disebabkan oleh peningkatan kepekatan dari larutan ekstrak yang mengakibatkan penurunan aktivitas antioksidannya. ${ }^{13}$ Selain itu, tingkat kepekatan ekstrak yang terlalu tinggi dapat menghambat saponin sebagai antibakteri untuk menembus membran sel bakteri. ${ }^{14}$ Dengan demikian efek dari ekstrak rosella dosis 0,33 $\mathrm{mg} / \mathrm{gBB}$ dan dosis 0,66 mg/gBB dalam penyembuhan ulser akan menurun jika dibandingkan dengan dosis 0,17 mg/gBB .

Senyawa aktif antosianin dalam ekstrak berfungsi sebagai antioksidan karena dapat menangkal radikal bebas. Pada fase inflamasi terbentuk radikal bebas Reactive Oxygen Species (ROS) yang dikeluarkan oleh netrofil dan makrofag sebagai bagian dari sistem imun. ROS yang berlebihan dapat merusak jaringan dan memperlambat penyembuhan luka. ${ }^{15}$ Pada konsentrasi tinggi, aktivitas antioksidan grup fenolik sering lenyap bahkan antioksidan tersebut menjadi prooksidan yang berefek negatif terhadap sel sehat dalam tubuh. ${ }^{16}$

Flavonoid dalam ekstrak rosella berfungsi sebagai antiiflamasi dengan penghambatan aktivitas enzim siklooksigenase dan lipooksigenase, penghambatan akumulasi leukosit, penghambatan degranulasi neutrophil, penghambatan pelepasan histamine.13 Penghambatan enzim siklooksigenase dan lipooksigenase dapat menyebabkan penghambatan sintesis leukotriene dan prostaglandin yang merupakan mediator inflamasi. Penghambatan akumulasi leukosit yang menghambat tromboksan akan menyebabkan penurunan respon tubuh terhadap inflamasi. Flavonoid juga menghambat degranulasi neutrophil yang akan mengurangi pelepasan asam arakhidonat oleh neutrofil. Selain itu, flavonoid berperan dalam penghambatan pelepasan histamine dari sel mast. ${ }^{17}$ Apabila flavonoid dikonsumsi secara berlebihan (dosis tinggi) dapat berperan sebagai mutagen dan menghambat enzim-enzim tertentu yang penting untuk metabolisme hormon. ${ }^{18}$

Senyawa tanin dalam ekstrak rosella mempunyai daya antibakteri yang bekerja dengan cara memprepitasi protein. Tanin dapat menghambat enzim reverse transkriptase dan DNA topoisomerase sehingga sel bakteri tidak dapat terbentuk. ${ }^{19}$ Tanin menginaktifkan adhesin sel mikroba, menginaktifkan enzim, dan menggangu transport protein pada lapisan dalam sel. Tanin mempunyai target pada polipeptida dinding sel sehingga pembentukan dinding sel menjadi kurang sempurna dan lisis karena tekanan osmotik maupun fisik. ${ }^{20}$

Saponin sebagai antibakteri dengan menurunkan tegangan permukaan sehingga mengakibatkan naiknya permeabilitas atau kebocoran sel dan mengakibatkan senyawa intraseluler akan keluar. ${ }^{19}$ Senyawa ini berdifusi melalui membran luar dan dinding sel yang rentan, lalu mengikat membran sitoplasma dan mengganggu serta mengurangi kestabilan itu. Hal ini menyebabkan sitoplasma bocor keluar dari sel yang mengakibatkan kematian sel. 21

Polifenol bekerja dengan cara membunuh mikroorganisme yaitu dengan mendenaturasi protein sel. Ikatan hidrogen yang terbentuk antara polifenol dan protein mengakibatkan struktur protein menjadi rusak. Ikatan hidrogen tersebut akan mempengaruhi permeabilitas dinding sel dan membran sitoplasma menyebabkan ketidakseimbangan makro molekul dan ion dalam sel, sehingga sel lisis. ${ }^{22}$

Vitamin C berfungsi menghambat kerusakan oksidatif terhadap suatu molekul target dengan cara bereaksi dengan radikal bebas reaktif membentuk yang relatif stabil. Vitamin C juga berperan sebagai bahan essensial dalam pembentukan kolagen dan elastin serta dalam proses penyembuuhan luka. ${ }^{23}$ Dalam studi terbaru menunjukkan 
bahwa $\mathrm{pH}$ yang rendah dari Vitamin $\mathrm{C}$ berfungsi sebagai antibakteri karena $\mathrm{pH}$ rendah menghambat pertumbuhan bakteri. ${ }^{24}$

\section{DAFTAR PUSTAKA}

1. Mendorfa, Arvian Novanolo. Ekstrak Daun Mangrove Mempercepat Kesembuhan Ulkus Traumatikus. Fakultas Kedokteran Gigi Universitas Hang Tuah. Surabaya, Indonesia. 2015.

2. Vorvick LJ., Zieve D. Mouth Ulcers on Medline Plus. A.D.A.M.Inc. 2012

3. Birnbaum W., Stephen MD. Oral Diagnosis: The Clinician's Guide. Editor :Lilian Juwono. Diagnosis Kelainan dalam Mulut, Petunjuk bagi Klinisi. EGC. Jakarta. 2010. Hal : 271-2.

4. Puspitasari D \& Apriasari ML. Analysis of Traumatic Ulcer Healing Time Under the Treatment of the Mauli banana (Musa acuminata) $25 \%$ Stem Extract Gel. Department of Oral Medicine Faculty of Dentistry Universitas Padjadjaran. 2017.

5. Rizki MI., Nurkhasanah, Tedjo Y., Laela, HN \& Krisana K. Antioxidant Activity of Nanoparticle from Rosella (Hibiscus sabdariffa L.) Calyx Extract Originated Indonesia and Thailand. Research Journal Of Pharmaceutical, Biological and Chemical Sciences. 2017; 8: 149-57.

6. Mungole A., \& Chaturvedi A. Hibiscus sabdariffa L., A Rich Source of Secondary Metabolites. International Journal of Pharmaceutical Sciences Review and Research. 2011; 6(1):83-7.

7. Dewi PS, Andreanus A, Manulang AM. Aktivitas Antiinflamasi Ekstrak Air Kelopak Bunga Rosela (Hibiscus Sabdariffa L) Pada Tikus Putih Galur Wistar Jantan. Fakultas Matematika Dan IImu Pengetahuan Alam, Universitas Jenderal Achmad Yani Bandung. 2014

8. Ramadhani N., Sumiwi SA. Aktivitas Antiinflamasi Berbagai Tanaman Diduga Berasal Dari Flavonoid. Fakultas Farmasi Universitas Padjadjaran. Suplemen 2016; 14 (2).

9. Endah Kusumastuti, Juni Handajani, \& Heni Susilowati. Ekspresi COX-2 dan Jumlah Neutrofil Fase Inflamasi pada Proses Penyembuhan Luka Setelah Pemberian Sistemik Ekstrak Etanolik Rosela (Hibiscus sabdariffa) (studi in vivo pada Tikus Wistar). Fakultas Kedokteran Gigi Institut Ilmu Kesehatan Bhakti Wiyata Kediri. 2014.

10. Cristian KR., Nir MG., Jackson JC. Antioksidant and Cyclooksigenase Inhibitory Activity of Sorrel (Hibiscus sabdariffa. J Food Comp and Analys). 2006; 19: $778-83$.
11. A Winnifred Christy,J Leelavathy,T Jones Raja Devathambi,VM Roobitha. Systemic Management of Recurrent Aphthous Stomatitis. C.S.I. College of Dental Sciences and Research, Madurai, Tamil Nadu, India. 2015.

12. Tarigan RN, Setyawati T. Tantangan Dalam Perawatan Oral Lichen Planus Pada Pasien Diabetes Melitus (Laporan Kasus). Fakultas Kedokteran Gigi, Universitas Indonesia. 2009.

13. Nijveldt RJ., Nod EV., Hoorn DECV., Boelens, PG., Noreen KV., Leeuwen PAMV. Flavonoids: a Review of Probable Mechanisms of Action and Potential Application. American Journall of Clinical and Nutrition. 2001; 74.

14. Rofillah P. Andhini. Efek Ekstrak Kulit Buah Naga Merah (Hylocereus Polyrhizus) Terhadap Jumlah Sel Fibroblas pada Soket Gigi Tikus Wistar. Fakultas Kedokteran Gigi Universitas Airlangga. Surabaya. 2016

15. McKelvey K., Xue M., Whitmont K., Shen K., Cooper, A., Jacson, C. Potential antiinflammatory treatments for chronic wounds. Wound Prac and Res. 2012; 20 (2):86-9.

16. Warganegara E, Restina D. Getah Jarak (Jatropha curcas L.) sebagai Penghambat Pertumbuhan Bakteri Streptococcus mutans pada Karies Gigi. Bagian Mikrobiologi, Fakultas Kedokteran, Universitas Lampung. 2016; 5(3).

17. Katzung BG. Farmakologi Dasar dan Klinik. Edisi X. BukU Kedokteran. EGC, Jakarta. 2010.

18. Sudirman T. Uji Efektivitas Ekstrak Daun Salam (Eugenia Polyantha) Terhadap Pertumbuhan Staphylococcus Aureus Secara In Vitro. Skripsi. Makassar :Universitas Hasanuddin Fakultas Kedokteran Gigi. 2014.

19. Agus Rochmat, Galih Liantony, Yuki Diens Septiananda. Uji Kemampuan Tanin Daun Ketapang Sebagai Inhibisi Korosi Pada Baja Mild Steel Dalam Pipeline. Universitas Sultan Ageng Tirtayasa. Jurnal Integrasi Proses 2019; 8(1): $45-50$.

20. Sari FP dan Sari SM. Ekstraksi Zat Aktif Antimikroba dari Tanaman Yodium (Jatropha multifida Linn) sebagai Bahan Baku Alternatif Antibiotik Alami. Semarang: Fakultas Teknik Universitas Diponegoro. 2011.

21. Cavalieri SJ, Rankin ID, Harbeck RJ, Sautter RS, McCarter YS, Sharp SE, Ortez $\mathrm{JH}$ \& Spiege CAl. Manual of Antimicrobial Susceptibility Testing. USA: American Society for Microbiology. 2005. 
22. Pratiwi RR, Sri L, Heru FT. Uji Aktivitas Antibakteri Ekstrak Etanol Daun Mangga Bacang (Mangifera Foetida L.) Terhadap Staphylococcus Aureus Secara In Vitro. Universitas Tanjungpura. 2014

23. Pakaya D. Peranan Vitamin C Pada Kulit. Fakultas Kedokteran Dan IImu Kesehatan
Universitas Tadulako. Jurnal Ilmiah Kedokteran, 2014; 1(2).

24. Mousavi S, Bereswill S, Heimesaat MM. Immunomodulatory and Antimocrobial Effect of Vitamin C. Euporean Journal of Microbiology and Immunology. 2019 